TP Periodica Polytechnica

Social and Management Sciences

22(1), pp. 47-56, 2014

DOI:10.3311/PPSo.7052

http://www.pp.bme.hu/article/view/so/7052

Creative Commons Attribution (i)

RESEARCH ARTICLE

\section{Survivorship Bias and Performance of Mutual Funds in Hungary}

Dariusz Filip

ReCeived 28 September 2013 ACcepted After ReVISION 13 February 2014

\section{Abstract}

The article aims at finding whether the survivorship bias significantly influences the achieved returns of the surviving mutual funds in Hungary. Furthermore, the article looks at the situation on financial market, and in particular at the moment of nationalizing the competitive pension funds and at the importance of inflow rates in finding reasons for failed funds dissolution. The empirical results indicate insignificance of survivorship bias in the analyzed mutual fund database in 2000-2012 period. The influence of the dissolved funds on the returns of surviving entities in given sub-periods was limited and evaluated differently for each type of funds. The indirectly drawn conclusions about the liquidation of funds resulting from the market conditions were partly confirmed. Moreover, the asset outflow of the funds classified as non-survivors was moderately correlated with an increase in the number of dissolved funds (but only in some sub-periods), which may be attributed to financial market situation.

\section{Keywords}

mutual funds $\cdot$ survivorship bias $\cdot$ mortality rate $\cdot$ emerging market

\section{Dariusz Filip}

Faculty of History and Social Sciences,

Cardinal Stefan Wyszynski University in Warsaw (UKSW), Poland

e-mail: d.filip@uksw.edu.pl

\section{Introduction}

In financial analyses, the database information is often truncated, which may result in selection bias such as survivorship bias. In relation to financial performance analysis, survivorship bias is defined as a tendency to exclude the failed entities from performance studies.

The exclusion of non-surviving companies from the database entails a risk of result distortion in performance analyses. It means that changing the number of financial institutions involved in the study on the data preparation stage may lead to spurious conclusions. In a sense, excluding some funds from the study limits its extent only to successful companies. It turns out that the advice companies creating various fund rankings for investors treat non-surviving funds as dead funds, and they might ignore their performance in their calculations.

The main reasons for asset management companies dissolution are economic and image aspects. That is to say, the reluctance of fund managers to show poor performance often triggers off a fund merger or dissolution. It is caused by natural selection: funds are withdrawn if they are unprofitable because of the asset outflow or poor performance in long period. Hence, these are only the successful funds that are able to survive the competition.

From the cognitive perspective, the findings concerning survivorship bias in performance broaden the knowledge on the similarities and differences existing between financial systems in various countries. Moreover, the findings concerning the significance of the investigated issue make it possible to evaluate the intensity of competition in the branch and describe the influence of market shocks on the functioning of financial institutions. Furthermore, the longevity analysis conducted using the rate of attrition and survivorship bias seems to be an important factor that shall be taken into consideration by investors in their long-term investment decisions.

The main aim of the article is to examine whether the survivorship bias significantly influences the returns achieved by the surviving mutual funds. Additionally, the implemented research approaches look at market situation and inflow rates in the survivorship bias analysis in Hungary. Thus, the empirical 
results of the study will be important for the investors using mutual fund ranking published by investment advice companies.

The remainder of this study is structured as follows. Section 2 provides a brief review of the existing literature. The research approach and the description of input data will be outlined in Section 3. Sections 4 and 5 present the empirical results obtained from the survivorship bias analysis and the ideas about the reasons for withdrawal of funds from the market. The summary of the major findings constitutes the ending part of the article.

\section{Related literature}

The analyzed issue is discussed in the mutual fund literature but focuses only on the US industry. In the CEE countries, where the industry is still emerging and new entities are set up more often than liquidated, the empirical research in this area is undertaken very rarely. However, there are studies analyzing the performance of Hungarian financial institutions. We can mention some of them: the study analyzing performance dependence in the Central European banking industry (Jackowicz, Kowalewski and Kozłowski [14]), the paper concerning pension funds' performance in Poland and Hungary (Bohl, Lischewski and Voronkova [4]), the paper examining the phenomenon of persistence in mutual fund performance in Hungary (Filip [10]) and the article proposing a new return calculation method for testing market efficiency and measuring Hungarian mutual fund performance (Erdös and Ormos [9]).

One of the most significant publications on financial economics is the paper by Jensen [15], dating to 1968. During the risk analysis of mutual funds, Jensen observed a certain performance predictability on the basis of alphas of regression equation for the rates of return of 56 funds in the period 1945-1964. Jensen's findings confirmed the market efficiency hypothesis (EMH).

However, the first study of survivorship issues ever published is the paper of Grinblatt and Titman [13], who have analyzed the US equity funds operating in the 1975-1984 period to determine whether the outperformance of investment returns is possible. Moreover, they tried to estimate the effect of survivorship bias and found out that it can influence the returns of surviving funds. The estimated annual survivorship bias was relatively small and equaled between 10 and 40 basis points. Nevertheless, the analyzed relation between the dissolved and existing funds was statistically insignificant.

Other authors, such as Brown, Goetzmann, Ibbotson and Ross [5] have tried to find a relationship between volatility and returns in a sample truncated by survivorship bias. The results obtained from the statistical test based on risk-adjusted return data as well as simulated values of cross-product ratio indicated the increase of predictability of fund managers' performance. Moreover, they have shown the persistence of the returns achieved in large biased samples.

The analysis of bond funds market using parametric and nonparametric methods was carried out by Blake, Elton and
Gruber [3]. By calculating excess risk-adjusted returns, they were able to examine performance for two different samples: survivorship biased and survivorship bias-free sample. They have proved that the obtained survivorship bias, which equaled 27 basis points for bond funds, can be important for surviving entities because of performance variability lower than in the case of equity funds. Owing to that, they have also found some limited evidence of performance predictability.

Elton, Gruber and Blake [8], in turn, have examined both the frequency of mutual funds disappearance and the impact of non-surviving funds on return. They applied raw return as well as risk-adjusted returns from both a single- and a multi-factor model. Beside the survivorship bias they have also examined the characteristics of equity funds. The obtained results corresponded well with prior findings. They have discovered that small funds and the ones with poor performance were less able to survive than their large peers. The results confirm performance overvaluation from 30 to 90 basis points due to excluding non-survivors from the sample.

Malkiel [17] using methodology slightly different from the ones presented in the previous papers, has observed that survivorship bias may be more important in an analysis of superior returns and performance persistence of equity funds. He found that the return increased about 150 basis points in the biased sample. Similarly, Carhart [7] taking into consideration the necessity of using survivorship bias-free mutual fund database, focused on the occurrence of performance persistence of equity funds. Moreover, by applying Malkiel's approach, Carhart has determined the impact of the dissolved funds on the returns of their surviving peers in 1962-1993 period, the estimated value of which equaled $3-5 \%$ a year. He has also shown that small funds with lower net asset inflow disappear much more often than bigger entities.

The following studies are related to financial institutions applying investment strategies riskier than traditional investment funds. The study of Ackermann, McEnally and Ravenscraft [1] concerns survivorship bias and performance of hedge funds in 1988-1995 period. Having implemented Malkiel's approach, which includes the difference between the surviving and disappearing funds, they have indicated that the survivorship bias is small $(0.16 \%)$ and statistically insignificant. However, they have noticed that this extremely low value of bias is inconsistent with the general impression that the hedge fund industry is riskier than the traditional mutual fund industry.

Liang [16] has investigated survivorship bias in hedge fund returns from the investment styles perspective. Having compared two large databases from 1994-1997 period, he was able to determine that the survivorship bias calculated as the difference between the returns of surviving funds and the returns of all funds is higher and exceeds $2 \%$ a year. At the same time, he stressed that it could be different across styles. Furthermore, the empirical results have shown that the main reason for fund 
disappearance is poor performance, especially when a dissolved fund is young and with small asset amount. These two last papers present various findings, but the discrepancies may result from different sources of data, time horizons or the applied methodological approaches.

$\mathrm{Bu}$ and Lacey [6] by means of domestic US equity funds data have reported a statistically significant performance difference between the return of surviving funds' portfolio and the return of live and dead funds' portfolio. They applied CAPM, Fama-French three-factor and four-factor models to the analysis of market risk factors. The Granger causality test for the study horizon from 1998 to 2004 has revealed the impact of the largecap index and the three-month T-bill rate on the value of bias. Moreover, the overestimated performance of surviving funds was noticed during prolonged downward market trend.

As mentioned before, the studies of mutual fund industries in the CEE countries focusing on the analyzed issue are very scarce. Thus, the paper of Gabrielczyk [12] concerning equity and mixed funds in Poland in 1999-2004 period is worth mentioning at this point. By means of Elton-Gruber-Blake's approach and measures of return (rate of return and Jensen's alpha) she has found maximal performance distortion of about 30 basis points. Nevertheless, the survivorship bias impact on returns of the analyzed entities was insignificant (at least for the time being, and it may change in future).

The study of Filip [11] provides similar findings. He examined Czech equity funds from the performance evaluation perspective. By the application of Malkiel's approach adjusted to the Czech reality, he has compared the mean returns of equity funds in the 2004-2010 period. The obtained results showed that survivorship bias for Czech mutual funds was statistically insignificant. However, the mean returns of the dissolved funds were much worse than their surviving peers, which is understandable as the funds with poor performance tend to disappear.

The insignificance of the results mentioned in the two last papers could have stemmed from the application of a relatively short study horizon, which also seems to explain a small number of observations. Moreover, the mutual fund industry in the CEE countries is still emerging and the number of funds both the functioning and particularly the non-surviving ones has always been low.

\section{Methodology and data characteristics}

The scope of the study includes publicly offered open ended mutual funds from BAMOSZ (Association of Hungarian Investment Fund and Asset Management Companies) database. It was possible to calculate the monthly return in period from January 2000 to December 2012 by means of daily unit prices of mutual funds operating in Hungary. Depending on investment policy, the author has divided the analyzed funds into four main categories, which are as follows: equity funds, mixed funds, bond funds and money market funds. By equity funds we understand the funds of stock investment policy. Absolute return, dynamic, deliberate and balanced funds fall into the category of mixed funds. Bond funds include short bond, unlimited duration bond and long bond funds. The last group, money market funds, consists of entities categorized depending on investment policy as liquidity funds and other money market funds.

The y-intercept of appropriately constructed regression equations is used in financial literature as a measure of return while analyzing survivorship bias. Thus, the models based on the CAPM assumption are estimated for all the four types of mutual funds.

The mentioned model for equity funds adopted a singlefactor equation:

$$
Y_{i, t}=\alpha_{i}+\beta_{M, i} Y_{M, t}+\varepsilon_{i, t}
$$

where: $Y_{i, t}$ is the rate of fund return in the period $t ; \alpha_{i}$ - means the unknown fund return represented by the so called Jensen's alpha; $\beta_{i}$ is the beta coefficient of the fund $i ; Y_{M, t}$ is the return of the stock market in the period $t$ calculated on the basis of changes in the local equity index; $\varepsilon_{i, t}$ means the random error in the period $t$. In this case, the applied benchmark was Budapest Stock Exchange Index (BUX). The BUX values come from the official webpage of the Magyar Nemzeti Bank (MNB).

As for mixed funds, it was necessary to introduce a second explanatory variable to the model (1):

$$
Y_{i, t}=\alpha_{i}+\beta_{M, i} Y_{M, t}+\beta_{B, i} Y_{B, t}+\varepsilon_{i, t}
$$

where: $Y_{B, t}$ means the return on the government securities calculated on the basis of change of the local bond index. The benchmark presents returns of the CMAX index (MAX Composite CA IB Securities), the values of which are recorded by Government Debt Management Agency Private Company Limited by Shares (AKK).

In order to investigate bond funds, the equity index should be replaced by risk-free return which is related to the investment profile of this particular category of funds:

$$
Y_{i, t}=\alpha_{i}+\beta_{B, i} Y_{B, t}+\beta_{F, i} Y_{F, t}+\varepsilon_{i, t}
$$

where: $Y_{F, t}$ means risk-free rate of return and includes treasury bill rates (T-Bill). The treasury bill rate is defined as weighted average yield on 90-day treasury bills sold at auctions. The risk-free values were taken from the monthly reports of the International Financial Statistics IMF.

For the last analyzed category of mutual funds, money market funds, the number of factors has been reduced to one, namely the values of T-Bill rates:

$$
Y_{i, t}=\alpha_{i}+\beta_{F, i} Y_{F, t}+\varepsilon_{i, t}
$$


All the estimated models are based on monthly observations, which means that reliable values of alpha parameters were to be obtained in a yearly horizon. The measures of funds' returns used in the study employ rates of return calculated using unit prices. The last measure omits the differences in risk level, but it can be used in the survivorship bias analysis as a support. The basic rate of return is calculated as:

$$
Y_{i, t}=\frac{U P_{i, t}-U P_{i, t-1}}{U P_{i, t-1}}
$$

where $Y_{i, t}$ is the rate of return of fund $i$ in period $t, U P_{i, t}$ is the unit price on fund $i$ in period $t$ and $U P_{i, t-1}$ in the preceding period $(t-1)$.

Two main research methods of survivorship bias analysis are distinguished in financial literature. The first one is about the difference between the mean return of all funds and the mean return of non-surviving funds (see Elton, Gruber and Blake [8]). The second, in turn, looks at the difference between the mean return of survivors and the mean return of non-survivors (see Malkiel [17]). The sample containing all funds includes survivors as well inactive ones that could have been terminated or suspended in the meantime. The non-surviving funds can be classified as dead, dissolved or merged entities. We shall apply both the mentioned methods in order to increase the precision of inferring. In further part of the paper, especially where tabular results are presented, I will use the following abbreviations relating to the method: $E-G-B$ for Elton-Gruber-Blake's approach and $M K L$ for Malkiel's approach.

The risk-adjusted returns will be used to estimate the survivorship bias in both the approaches presented above. As mentioned before, the regression intercepts of specifically constructed models (CAPM) will be utilized in the study as well as auxiliary rates of return calculated separately for each fund. The difference between average returns in the analyzed investment portfolios that can be observed in particular years and in the whole period under study will stand for the value of the estimated survivorship bias. The significance of the obtained results depends on the values of student's $t$-test for independent samples at the last stage of the analysis. The student's $t$-test is calculated according to the following formula:

$$
t_{S}=\frac{\bar{x}_{A}-\bar{x}_{B}}{\sqrt{\frac{S D_{A}^{2}}{n_{A}}+\frac{S D_{B}^{2}}{n_{B}}}}
$$

where: $\bar{x}_{A}$ and $\bar{x}_{B}$ refer to mean performance in A group (depending on the applied research method: for survivors or all the entities in the analyzed period) and B group (only non-survivors); $S D$ stands for standard deviations of performance; $n$ is the size of group A or B.
Moreover, the measure of asset net inflow of mutual funds, calculated as a ratio of inflow and outflow, will be useful to find reasons of funds' dissolution. For mutual funds the inflow rate is given as follows:

$$
\text { Flow }_{i, t}=\frac{N A_{i, t}-N A_{i, t-1}\left(1+Y_{i, t-1}\right)}{N A_{i, t-1}}
$$

where: Flow $w_{i, t}$ means inflow rate of $i$-fund in period $t, N A_{i, t}$ is the net asset value on $i$-fund in the period $t$ and $N A_{i, t-1}$ is the net asset value on $i$-fund in the preceding period $(t-1)$.

On the basis of the presented data and applied methodology, it will be possible to provide direct evidence for the influence of survivorship bias on the achieved returns of surviving mutual funds. The analysis concerning reasons of funds' dissolution will be possible only through indirect reasoning, which consists in comparing the obtained results with market situation and asset net inflow of mutual funds.

\section{Empirical results}

The main section of the paper dealing with survivorship bias analysis contains a comparison of mean returns achieved by mutual funds in Hungary in 2000-2012 period. We have utilized two following measures of return: rates of returns and Jensen's alphas. With regard to the differences in biases discussed in finance literature and depending on risk, investment style or geographical profile we have decided to take investment policy into consideration in our analyzes.

As mentioned in methodology section, survivorship bias was calculated according to the two approaches: Elton-GruberBlake's $(E-G-B)$ and Malkiel's $(M K L)$ approach. Moreover, the tables present the values of annual mortality rate (the so called rate of attrition) calculated as a proportion of number of funds dying during the given year to the number of all funds operating from the beginning of the year.

The disappearance of some equity funds observed in 20002012 period did not cause such a reduction in the offer of Hungarian mutual funds applying stock investment policy that would be noticeable to clients. As we can see in Table 1, relatively many funds in Hungary were dissolved after the appearance of financial crisis in 2008. As many as 8 out of 67 funds functioning in the year that brought the global recession did not survive. However, new financial institutions replacing the nonsurviving entities have been emerging each year from the beginning of the analyzed period. The highest values of mortality rate amounting to over 16\% were noticed in 2001-2004 period, when there were no well-defined tendencies on the stock market. Statistically significant values of survivorship bias, calculated by rates of return while adopting both the approaches, can be observed in the middle of that period, namely in 2003 . The 
bias estimation for the second measure (Jensen's alphas) did not provide statistically significant values.

As for the analyzed type of funds, the mean returns obtained by the dissolved funds, higher than the returns of their peers surviving in the beginning of the crisis (2007-2008) seem very interesting. This observation is unfavorable to the thesis about poor performance as the reason for the disappearance of failed funds, at least during the time of dynamic changes in financial markets.

The results achieved by the second category of funds (mixed funds) presented in Table 2, show more important fluctuations of the number of entities offering investment possibilities to clients. Almost till the end of 2009, the yearly mortality rate reached nearly two-digit values. It may seem disturbing from the perspective of keeping a diversified offer for clients interested in mixed funds in Hungary. The mean value of mortality rate within the analyzed period equaled nearly $13 \%$. The statistically significant values of survivorship bias were noticed in 2001, 2005-2006 and 2009, when mean differences of rates of returns between the analyzed sub-groups of funds equaled nearly 0.008 bias' basis points in some cases. A similar scenario took place in 2003 and 2009: by using Jensen's alphas we were able to notice higher absolute differences. The returns of failed funds were poorer than the surviving ones during the time of the increase in mixed funds' number in Hungary.
Similarly as in the previous case, the mortality rates of bond funds were given in two-digit values (amounting even to $27 \%$ ) till 2008 (see Table 3). The mean value of the ratio exceeded $13 \%$ in the whole period under study, which is the highest mean value among all the analyzed funds. However, the differences in the rates of return achieved by the analyzed subgroups of funds only in one year (2007) were statistically significant following Elton-Gruber-Blake's approach as well as Malkiel's method. The lack of statistical significance of biases calculated for Jensen's alphas and the unavailability of data covering the last years of the study's horizon entail that the results obtained by means of the risk-adjusted measure should be treated very carefully.

The significant values of mortality rate for money market funds occurred in 2007-2009 period as suggested in Table 4. At the same time, statistically significant values of bias, calculated for rates of return or Jensen's alphas may, as mentioned before, result from market situation. Furthermore, the values of survivorship bias calculated for the rate of return in 2003-2004 seem to be interesting. Exactly at that time the important changes influenced the profitability of securities on the treasury market. Moreover, till 2004 the dissolved funds of the analyzed category have achieved better returns than their surviving peers (although it could be related to the low number of non-survivors).

In general, the occurrence of survivorship bias in a database limits the possibilities of evaluation applied to long-term

Tab. 1. Survivorship bias observed in equity funds performance

\begin{tabular}{|c|c|c|c|c|c|c|c|c|c|c|c|c|c|}
\hline \multirow[b]{2}{*}{ Year } & \multirow[b]{2}{*}{$\begin{array}{c}\text { Number } \\
\text { of } \\
\text { Survivors }\end{array}$} & \multirow[b]{2}{*}{$\begin{array}{l}\text { Number } \\
\text { of Non- } \\
\text { Survivors }\end{array}$} & \multicolumn{3}{|c|}{ Rate of Return } & \multicolumn{3}{|c|}{ Jensen's Alpha } & \multirow[b]{2}{*}{$\begin{array}{c}\text { Mortality } \\
\text { Rate }\end{array}$} & \multicolumn{2}{|c|}{ Rate of Return } & \multicolumn{2}{|c|}{ Jensen's Alpha } \\
\hline & & & $\begin{array}{l}\text { Total } \\
\text { Funds }\end{array}$ & $\begin{array}{l}\text { Survived } \\
\text { Funds }\end{array}$ & $\begin{array}{l}\text { Non- } \\
\text { Survived } \\
\text { Funds }\end{array}$ & $\begin{array}{c}\text { Total } \\
\text { Funds }\end{array}$ & $\begin{array}{l}\text { Survived } \\
\text { Funds }\end{array}$ & $\begin{array}{l}\text { Non- } \\
\text { Survived } \\
\text { Funds }\end{array}$ & & $\begin{array}{c}\text { Bias for } \\
E-G-B \\
\text { method }\end{array}$ & $\begin{array}{l}\text { Bias for } \\
M K L \\
\text { method }\end{array}$ & $\begin{array}{l}\text { Bias for } \\
E-G-B \\
\text { method }\end{array}$ & $\begin{array}{l}\text { Bias for } \\
M K L \\
\text { method }\end{array}$ \\
\hline 2000 & 21 & 2 & $-0,0050$ & $-0,0045$ & $-0,0097$ & 0,0013 & 0,0013 & n.a. & $8,70 \%$ & 0,0047 & 0,0052 & n.a. & n.a. \\
\hline 2001 & 24 & 5 & $-0,0087$ & $-0,0086$ & $-0,0095$ & $-0,0083$ & $-0,0078$ & $-0,0134$ & $17,24 \%$ & 0,0007 & 0,0009 & 0,0052 & 0,0057 \\
\hline 2002 & 26 & 5 & $-0,0093$ & $-0,0092$ & $-0,0096$ & $-0,0138$ & $-0,0140$ & $-0,0128$ & $16,13 \%$ & 0,0003 & 0,0004 & $-0,0010$ & $-0,0012$ \\
\hline 2003 & 27 & 6 & 0,0121 & 0,0130 & 0,0084 & 0,0060 & 0,0066 & 0,0031 & $18,18 \%$ & $* * 0,0037$ & $* * 0,0045$ & 0,0029 & 0,0035 \\
\hline 2004 & 29 & 6 & 0,0142 & 0,0149 & 0,0106 & $-0,0037$ & $-0,0041$ & $-0,0009$ & $17,14 \%$ & 0,0035 & 0,0043 & $-0,0028$ & $-0,0033$ \\
\hline 2005 & 30 & 3 & 0,0212 & 0,0213 & 0,0197 & 0,0098 & 0,0102 & 0,0060 & $9,09 \%$ & 0,0015 & 0,0017 & 0,0038 & 0,0042 \\
\hline 2006 & 34 & 4 & 0,0119 & 0,0120 & 0,0103 & 0,0050 & 0,0051 & 0,0038 & $10,53 \%$ & 0,0016 & 0,0018 & 0,0011 & 0,0012 \\
\hline 2007 & 43 & 5 & 0,0016 & 0,0015 & 0,0021 & 0,0021 & 0,0021 & 0,0019 & $10,42 \%$ & $-0,0005$ & $-0,0006$ & 0,0002 & 0,0002 \\
\hline 2008 & 59 & 8 & $-0,0388$ & $-0,0404$ & $-0,0271$ & $-0,0074$ & $-0,0074$ & $-0,0072$ & $11,94 \%$ & $-0,0118$ & $-0,0134$ & $-0,0002$ & $-0,0002$ \\
\hline 2009 & 76 & 7 & 0,0292 & 0,0303 & 0,0166 & 0,0037 & 0,0037 & 0,0039 & $8,43 \%$ & 0,0126 & 0,0138 & $-0,0002$ & $-0,0002$ \\
\hline 2010 & 92 & 3 & 0,0145 & 0,0146 & 0,0120 & 0,0126 & 0,0127 & 0,0102 & $3,16 \%$ & 0,0025 & 0,0026 & 0,0024 & 0,0025 \\
\hline 2011 & 138 & 3 & $-0,0007$ & $-0,0004$ & $-0,0126$ & 0,0021 & 0,0021 & n.a. & $2,13 \%$ & 0,0120 & 0,0122 & n.a. & n.a. \\
\hline 2012 & 144 & 1 & 0,0104 & 0,0105 & $-0,0037$ & 0,0067 & 0,0067 & n.a. & $0,69 \%$ & 0,0141 & 0,0142 & n.a. & n.a. \\
\hline Mean & 57,2 & 4,5 & 0,0040 & 0,0042 & 0,0006 & 0,0012 & 0,0013 & $-0,0005$ & $7,24 \%$ & 0,0035 & $\mathbf{0 , 0 0 3 7}$ & 0,0018 & 0,0018 \\
\hline & & & & & & & & & t-test & 0,5817 & 0,6104 & n.a. & n.a. \\
\hline
\end{tabular}

Note: ***,*** indicate significance level for $t$-test of $10 \%, 5 \%$ and $1 \%$, respectively; n.a. stands for unavailable data; $E$ - $G$ - $B$ means the approach of Elton, Gruber and Blake [8]; MKL means the approach of Malkiel [17]. Source: Own estimates. 
Tab. 2. Survivorship bias observed in mixed funds performance

\begin{tabular}{|c|c|c|c|c|c|c|c|c|c|c|c|c|c|}
\hline \multirow[b]{2}{*}{ Year } & \multirow[b]{2}{*}{$\begin{array}{c}\text { Number } \\
\text { of } \\
\text { Survivors }\end{array}$} & \multirow[b]{2}{*}{$\begin{array}{l}\text { Number } \\
\text { of Non- } \\
\text { Survivors }\end{array}$} & \multicolumn{3}{|c|}{ Rate of Return } & \multicolumn{3}{|c|}{ Jensen's Alpha } & \multirow[b]{2}{*}{$\begin{array}{c}\text { Mortality } \\
\text { Rate }\end{array}$} & \multicolumn{2}{|c|}{ Rate of Return } & \multicolumn{2}{|c|}{ Jensen's Alpha } \\
\hline & & & $\begin{array}{c}\text { Total } \\
\text { Funds }\end{array}$ & $\begin{array}{l}\text { Survived } \\
\text { Funds }\end{array}$ & $\begin{array}{l}\text { Non- } \\
\text { Survived } \\
\text { Funds }\end{array}$ & $\begin{array}{l}\text { Total } \\
\text { Funds }\end{array}$ & $\begin{array}{l}\text { Survived } \\
\text { Funds }\end{array}$ & $\begin{array}{c}\text { Non- } \\
\text { Survived } \\
\text { Funds }\end{array}$ & & $\begin{array}{l}\text { Bias for } \\
E-G-B \\
\text { method }\end{array}$ & $\begin{array}{l}\text { Bias for } \\
M K L \\
\text { method }\end{array}$ & $\begin{array}{c}\text { Bias for } \\
E-G-B \\
\text { method }\end{array}$ & $\begin{array}{l}\text { Bias for } \\
M K L \\
\text { method }\end{array}$ \\
\hline 2000 & 7 & 2 & 0,0035 & 0,0030 & 0,0052 & 0,0031 & 0,0049 & $-0,0023$ & $22,22 \%$ & $-0,0017$ & $-0,0022$ & 0,0054 & 0,0072 \\
\hline 2001 & 8 & 2 & 0,0008 & $-0,0003$ & 0,0054 & 0,0032 & 0,0053 & $-0,0042$ & $20,00 \%$ & $*_{-}-0,0046$ & $* *-0,0057$ & 0,0074 & 0,0095 \\
\hline 2002 & 9 & 2 & 0,0026 & 0,0019 & 0,0054 & $-0,0011$ & $-0,0011$ & $-0,0011$ & $18,18 \%$ & $-0,0028$ & $-0,0034$ & 0,0000 & 0,0000 \\
\hline 2003 & 10 & 3 & 0,0064 & 0,0076 & 0,0026 & 0,0033 & 0,0043 & $-0,0011$ & $23,08 \%$ & 0,0039 & 0,0050 & $* * 0,0044$ & $* * 0,0054$ \\
\hline 2004 & 15 & 3 & 0,0125 & 0,0130 & 0,0099 & $-0,0050$ & $-0,0061$ & 0,0056 & $16,67 \%$ & 0,0026 & 0,0031 & $-0,0107$ & $-0,0117$ \\
\hline 2005 & 19 & 2 & 0,0108 & 0,0116 & 0,0037 & 0,0075 & 0,0078 & 0,0033 & $9,52 \%$ & $* * * 0,0072$ & $* * * 0,0079$ & 0,0042 & 0,0044 \\
\hline 2006 & 41 & 8 & 0,0091 & 0,0100 & 0,0043 & 0,0039 & 0,0044 & $-0,0019$ & $16,33 \%$ & $* 0,0048$ & $* 0,0057$ & 0,0058 & 0,0063 \\
\hline 2007 & 54 & 14 & 0,0050 & 0,0050 & 0,0049 & 0,0045 & 0,0047 & 0,0035 & $20,59 \%$ & 0,0001 & 0,0001 & 0,0011 & 0,0012 \\
\hline 2008 & 65 & 14 & $-0,0088$ & $-0,0081$ & $-0,0118$ & $-0,0013$ & $-0,0006$ & $-0,0046$ & $17,72 \%$ & 0,0031 & 0,0037 & 0,0033 & 0,0040 \\
\hline 2009 & 74 & 14 & 0,0139 & 0,0148 & 0,0088 & 0,0059 & 0,0064 & $-0,0017$ & $15,91 \%$ & $* * 0,0050$ & $* * 0,0060$ & $* * 0,0076$ & $* * 0,0082$ \\
\hline 2010 & 83 & 7 & 0,0069 & 0,0070 & 0,0064 & 0,0088 & 0,0089 & 0,0069 & $7,78 \%$ & 0,0005 & 0,0005 & 0,0020 & 0,0021 \\
\hline 2011 & 100 & 8 & $-0,0003$ & 0,0003 & $-0,0072$ & 0,0007 & 0,0012 & $-0,0079$ & $7,41 \%$ & 0,0069 & 0,0075 & 0,0086 & 0,0091 \\
\hline 2012 & 109 & 7 & 0,0049 & 0,0050 & 0,0031 & 0,0060 & 0,0060 & n.a. & $6,03 \%$ & 0,0018 & 0,0019 & n.a. & n.a. \\
\hline Mean & 45,69 & 6,62 & 0,0052 & 0,0055 & 0,0031 & 0,0030 & 0,0036 & $-0,0005$ & $12,65 \%$ & 0,0021 & 0,0023 & 0,0035 & 0,0040 \\
\hline & & & & & & & & & t-test & 0,7989 & 0,8805 & n.a. & n.a. \\
\hline
\end{tabular}

Note: $* * *, * * *$ indicate significance level for t-test of $10 \%, 5 \%$ and $1 \%$, respectively; n.a. stands for unavailable data; E-G-B means the approach of Elton, Gruber and Blake [8]; MKL means the approach of Malkiel [17]. Source: Own estimates.

Tab. 3. Survivorship bias observed in bond funds performance

\begin{tabular}{|c|c|c|c|c|c|c|c|c|c|c|c|c|c|}
\hline \multirow[b]{2}{*}{ Year } & \multirow[b]{2}{*}{$\begin{array}{c}\text { Number } \\
\text { of } \\
\text { Survivors }\end{array}$} & \multirow[b]{2}{*}{$\begin{array}{l}\text { Number } \\
\text { of Non- } \\
\text { Survivors }\end{array}$} & \multicolumn{3}{|c|}{ Rate of Return } & \multicolumn{3}{|c|}{ Jensen's Alpha } & \multirow[b]{2}{*}{$\begin{array}{c}\text { Mortality } \\
\text { Rate }\end{array}$} & \multicolumn{2}{|c|}{ Rate of Return } & \multicolumn{2}{|c|}{ Jensen's Alpha } \\
\hline & & & $\begin{array}{l}\text { Total } \\
\text { Funds }\end{array}$ & $\begin{array}{l}\text { Survived } \\
\text { Funds }\end{array}$ & $\begin{array}{c}\text { Non- } \\
\text { Survived } \\
\text { Funds }\end{array}$ & $\begin{array}{l}\text { Total } \\
\text { Funds }\end{array}$ & $\begin{array}{l}\text { Survived } \\
\text { Funds }\end{array}$ & $\begin{array}{l}\text { Non- } \\
\text { Survived } \\
\text { Funds }\end{array}$ & & $\begin{array}{l}\text { Bias for } \\
E-G-B \\
\text { method }\end{array}$ & $\begin{array}{l}\text { Bias for } \\
M K L \\
\text { method }\end{array}$ & $\begin{array}{l}\text { Bias for } \\
E-G-B \\
\text { method }\end{array}$ & $\begin{array}{l}\text { Bias for } \\
M K L \\
\text { method }\end{array}$ \\
\hline 2000 & 16 & 3 & 0,0080 & 0,0081 & 0,0073 & 0,0248 & 0,0087 & 0,2180 & $15,79 \%$ & 0,0006 & 0,0007 & $-0,1932$ & $-0,2093$ \\
\hline 2001 & 19 & 3 & 0,0075 & 0,0076 & 0,0064 & 0,0068 & 0,0069 & 0,0064 & $13,64 \%$ & 0,0010 & 0,0012 & 0,0004 & 0,0005 \\
\hline 2002 & 20 & 3 & 0,0057 & 0,0059 & 0,0046 & $-0,0062$ & $-0,0020$ & $-0,0327$ & $13,04 \%$ & 0,0011 & 0,0013 & 0,0266 & 0,0308 \\
\hline 2003 & 20 & 5 & 0,0010 & 0,0015 & $-0,0007$ & 0,0038 & 0,0036 & 0,0051 & $20,00 \%$ & 0,0017 & 0,0022 & $-0,0013$ & $-0,0015$ \\
\hline 2004 & 21 & 7 & 0,0084 & 0,0093 & 0,0058 & 0,0193 & 0,0173 & 0,0293 & $25,00 \%$ & 0,0026 & 0,0034 & $-0,0100$ & $-0,0120$ \\
\hline 2005 & 21 & 8 & 0,0053 & 0,0063 & 0,0028 & $-0,0050$ & $-0,0021$ & $-0,0171$ & $27,59 \%$ & 0,0025 & 0,0035 & 0,0121 & 0,0150 \\
\hline 2006 & 21 & 7 & 0,0036 & 0,0042 & 0,0019 & $-0,0011$ & 0,0010 & $-0,0074$ & $25,00 \%$ & 0,0017 & 0,0023 & 0,0063 & 0,0085 \\
\hline 2007 & 26 & 8 & 0,0031 & 0,0035 & 0,0017 & $-0,0144$ & $-0,0040$ & $-0,0457$ & $23,53 \%$ & $* 0,0013$ & $* * 0,0017$ & 0,0313 & 0,0417 \\
\hline 2008 & 26 & 9 & $-0,0003$ & 0,0007 & $-0,0031$ & 0,0137 & 0,0114 & 0,0441 & $25,71 \%$ & 0,0028 & 0,0038 & $-0,0304$ & $-0,0327$ \\
\hline 2009 & 34 & 3 & 0,0080 & 0,0087 & $-0,0003$ & 0,0037 & 0,0037 & n.a. & $8,11 \%$ & 0,0082 & 0,0089 & n.a. & n.a. \\
\hline 2010 & 35 & 0 & 0,0050 & 0,0050 & n.a. & 0,0023 & 0,0023 & n.a. & $0,00 \%$ & n.a. & n.a. & n.a. & n.a. \\
\hline 2011 & 42 & 0 & 0,0257 & 0,0257 & n.a. & 0,0038 & 0,0038 & n.a. & $0,00 \%$ & n.a. & n.a. & n.a. & n.a. \\
\hline 2012 & 54 & 0 & 0,0120 & 0,0120 & n.a. & 0,0043 & 0,0043 & n.a. & $0,00 \%$ & n.a. & n.a. & n.a. & n.a. \\
\hline Mean & 27,31 & 4,31 & 0,0071 & 0,0076 & 0,0027 & 0,0043 & 0,0042 & 0,0222 & $13,63 \%$ & 0,0045 & 0,0049 & $-0,0179$ & $-0,0180$ \\
\hline & & & & & & & & & t-test & 1,1089 & 1,1967 & n.a. & n.a. \\
\hline
\end{tabular}

Note: $* * *, * * *$ indicate significance level for $t$-test of $10 \%, 5 \%$ and $1 \%$, respectively; n.a. stands for unavailable data; $E$ - $G-B$ means the approach of Elton, Gruber and Blake [8]; MKL means the approach of Malkiel [17]. Source: Own estimates. 
Tab. 4. Survivorship bias observed in money market funds performance

\begin{tabular}{|c|c|c|c|c|c|c|c|c|c|c|c|c|c|}
\hline \multirow[b]{2}{*}{ Year } & \multirow[b]{2}{*}{$\begin{array}{l}\text { Number } \\
\text { of } \\
\text { Survivors }\end{array}$} & \multirow[b]{2}{*}{$\begin{array}{l}\text { Number } \\
\text { of Non- } \\
\text { Survivors }\end{array}$} & \multicolumn{3}{|c|}{ Rate of Return } & \multicolumn{3}{|c|}{ Jensen's Alpha } & \multirow[b]{2}{*}{$\begin{array}{c}\text { Mortality } \\
\text { Rate }\end{array}$} & \multicolumn{2}{|c|}{ Rate of Return } & \multicolumn{2}{|c|}{ Jensen's Alpha } \\
\hline & & & $\begin{array}{c}\text { Total } \\
\text { Funds }\end{array}$ & $\begin{array}{c}\text { Survived } \\
\text { Funds }\end{array}$ & $\begin{array}{c}\text { Non- } \\
\text { Survived } \\
\text { Funds }\end{array}$ & $\begin{array}{l}\text { Total } \\
\text { Funds }\end{array}$ & $\begin{array}{l}\text { Survived } \\
\text { Funds }\end{array}$ & $\begin{array}{c}\text { Non- } \\
\text { Survived } \\
\text { Funds }\end{array}$ & & $\begin{array}{l}\text { Bias for } \\
E-G-B \\
\text { method }\end{array}$ & $\begin{array}{c}\text { Bias for } \\
M K L \\
\text { method }\end{array}$ & $\begin{array}{l}\text { Bias for } \\
E-G-B \\
\text { method }\end{array}$ & $\begin{array}{l}\text { Bias for } \\
M K L \\
\text { method }\end{array}$ \\
\hline 2000 & 10 & 1 & 0,0067 & 0,0066 & 0,0078 & 0,0717 & 0,0979 & $-0,0851$ & $9,09 \%$ & $-0,0011$ & $-0,0013$ & 0,1569 & 0,1830 \\
\hline 2001 & 13 & 1 & 0,0060 & 0,0058 & 0,0082 & $-0,0035$ & $-0,0040$ & 0,0022 & $7,14 \%$ & $-0,0022$ & $-0,0023$ & $-0,0057$ & $-0,0063$ \\
\hline 2002 & 19 & 1 & 0,0052 & 0,0052 & 0,0063 & 0,0026 & 0,0016 & 0,0162 & $5,00 \%$ & $-0,0011$ & $-0,0011$ & $-0,0136$ & $-0,0145$ \\
\hline 2003 & 19 & 2 & 0,0041 & 0,0040 & 0,0051 & 0,0047 & 0,0048 & 0,0035 & $9,52 \%$ & $* *_{-0,0010}$ & $* *-0,0012$ & 0,0012 & 0,0013 \\
\hline 2004 & 21 & 2 & 0,0068 & 0,0066 & 0,0085 & 0,0150 & 0,0159 & 0,0063 & $8,70 \%$ & $* *_{-0,0017}$ & $* *-0,0019$ & 0,0087 & 0,0096 \\
\hline 2005 & 28 & 3 & 0,0047 & 0,0048 & 0,0035 & $-0,0019$ & $-0,0019$ & $-0,0018$ & $9,68 \%$ & 0,0012 & 0,0013 & $-0,0001$ & $-0,0001$ \\
\hline 2006 & 33 & 5 & 0,0047 & 0,0049 & 0,0032 & 0,0071 & 0,0076 & $-0,0005$ & $13,16 \%$ & 0,0015 & 0,0017 & 0,0076 & 0,0081 \\
\hline 2007 & 40 & 8 & 0,0042 & 0,0046 & 0,0026 & $-0,0096$ & $-0,0115$ & 0,0011 & $16,67 \%$ & $* * 0,0016$ & $* * 0,0019$ & $-0,0107$ & $-0,0126$ \\
\hline 2008 & 46 & 10 & 0,0029 & 0,0034 & 0,0010 & 0,0138 & 0,0179 & $-0,0189$ & $17,86 \%$ & 0,0019 & 0,0024 & $* * 0,0328$ & $* * 0,0368$ \\
\hline 2009 & 58 & 10 & 0,0049 & 0,0051 & 0,0035 & 0,0071 & 0,0074 & 0,0040 & $14,71 \%$ & 0,0013 & $* 0,0016$ & 0,0031 & 0,0035 \\
\hline 2010 & 60 & 8 & 0,0030 & 0,0031 & 0,0023 & 0,0030 & 0,0030 & 0,0034 & $11,76 \%$ & 0,0007 & 0,0008 & $-0,0004$ & $-0,0004$ \\
\hline 2011 & 63 & 7 & 0,0032 & 0,0033 & 0,0024 & 0,0024 & 0,0024 & n.a. & $10,00 \%$ & 0,0009 & 0,0010 & n.a. & n.a. \\
\hline 2012 & 64 & 1 & 0,0042 & 0,0042 & 0,0045 & 0,0035 & 0,0035 & n.a. & $1,54 \%$ & $-0,0002$ & $-0,0002$ & n.a. & n.a. \\
\hline Mean & 36,46 & 4,54 & 0,0047 & 0,0047 & 0,0045 & 0,0089 & 0,0111 & $-0,0063$ & $11,07 \%$ & 0,0001 & 0,0002 & 0,0153 & 0,0175 \\
\hline & & & & & & & & & t-test & n.a. & n.a. & n.a. & n.a. \\
\hline
\end{tabular}

Note: ***,*** indicate significance level for $t$-test of $10 \%, 5 \%$ and $1 \%$, respectively; $n . a$. stands for unavailable data; $E$ - $G$ - $B$ means the approach of Elton, Gruber and Blake [8]; MKL means the approach of Malkiel [17]. Source: Own estimates.

investment strategies by collective investment companies and leads to over-simplification of the analyzes concerning performance. However, the examination of Hungarian mutual funds industry showed an insignificant influence of survivorship bias in 2000-2012 horizon. The influence of the dissolved funds on the returns of surviving entities in given sub-periods was limited and construed variously in each type of funds. The significant changes in absolute biases during the period of changes in economic situation are worth attention. As for future analyzes of survivorship bias in other CEE countries, it would be worth lengthening the horizon of the study and examining a greater number of mutual funds.

\section{The causes of funds' liquidation}

The investigation resulted in an observation that the financial market situation may influence the non-surviving funds, which requires confirmation. The other reason for funds' liquidation discussed in financial literature is the outflow of assets of failed funds. We will try to find reasons for the withdrawal of funds from the market by verifying the hypotheses using indirect means.

The empirical results presented in Section 4 showed some temporal connections between funds' returns and the financial market situation in Hungary. The number of dissolved funds in a given year could stem from the increase or decrease in market factors and consequently from changes of net sales of unit shares. Figure 1 presents values of benchmarks of mutual funds in Hungary: Budapest Stock Exchange Index (BUX), bond index (CMAX), global equity index (MSCI) and risk-free returns (T-Bill rates) in 2000-2012 period.

During the global recession at the end of 2007, a downward trend occurred on global markets as well as the Budapest Stock Exchange (see Figure 1). An increase in mortality of equity funds was observed in the next year and surviving funds had worse performance than their non-surviving peers. Moreover, it was noticed that at the beginning of the analyzed period when the horizontal trend dominated on the stock market, the number of dissolved funds was twice as high as the mean mortality. With a relatively low number of funds operating at that time the rate of attrition rocketed and amounted to $16-18 \%$ in the 2001-2004 period.

This high rate of attrition for mixed funds maintained during the prevailing part of the study horizon could be a consequence of a low number of observations (below 50 entities), especially before 2007. Nevertheless, the liquidation of 14 mixed funds that took place each year in 2007-2009 period could be related to the above mentioned occurrence of financial crisis observed on the stock market as well as on bond market. Bond funds seem very sensitive to short-term changes in market sentiments on bond and treasury markets. However, the extremely high 


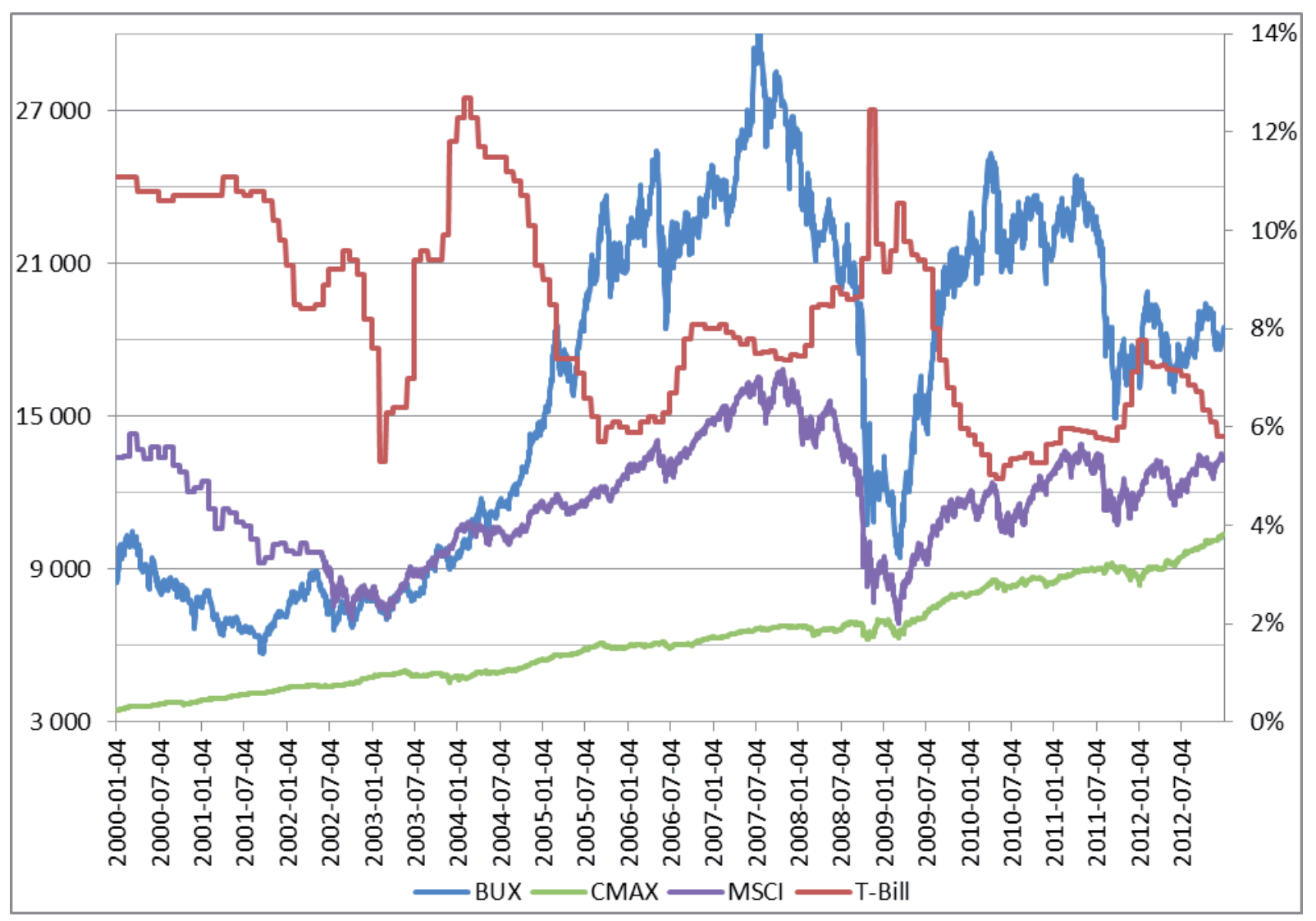

Fig. 1. Financial market factors in the survivorship analysis

Note: By the end of May 2002, the MSCI World Index had been calculated monthly.

Source: own compilation on the basis of the Magyar Nemzeti Bank (BUX), AKK - Government Debt Management Agency Private Company Limited by Shares (MAX Composite CA IB Securities), Morgan Stanley Capital International (MSCI) statistics and IMF International Financial Statistics database (T-Bill rate).

mortality rates in 2003-2008 period, which equaled over $20 \%$ per year, could be caused partly by the use of a small sample. The findings from the mortality rate analysis for money market funds confirm that the funds' subsistence depends significantly on market factors. The highest mortality accompanied by numerous observations for that market was noticed precisely at the time of biggest market changes in 2007-2009 period.

Another connection between the financial institutions' liquidation periods and market situation is visible on the example of the events that took place in Hungary towards the end of 2010, when the Hungarian parliament had enacted a bill implementing the possibility to use a part of the accumulated pension capital by the citizens to reduce Hungary's excessive public debt (see Simonovits [18] and Barbone [2]). The nationalization of pension funds through eliminating the second pillar may have persuaded individual investors to use the operating mutual funds (especially less risky ones) as a substitution for pension funds in order to satisfy their needs of long-term saving. From that moment on, a liquidation of mutual funds was occasionally observed in all types of funds. The Figure 2 presents a level of mortality rate (the right scale) plotted with net inflow (the left scale) of non-surviving funds.
The indirectly observed relationship between the changes in the financial market and the increase or decrease in fund mortality in Hungary makes our conclusions (presented in Section 4) legitimate. Furthermore, the asset inflow and outflow analysis of Hungarian funds juxtaposed with mortality rates will be used as a support in the examination of possible reasons for the liquidation of the analyzed financial institutions.

A quarterly asset outflow of the funds classified as nonsurvivors (as presented in Figure 2) partly correlates with an increase in the number of dissolved funds. It can be noticed that from 2008 to the half of 2009 the investors avoided bond funds on a large scale. Smaller but prolonged outflow of assets was observed in the rest of analyzed groups of funds, which is a consequence of financial market situation at that time. However, the observed change of the tendency may, as mentioned before, be caused by the nationalization of pension system in Hungary. In general, by means of indirect reasoning, it is difficult to find unequivocal arguments confirming that funds' disappearance depends on the ratios of asset inflow and outflow.

The obtained results justify future efforts to undertake further research concerning the analyzed problem the more so that the number of entities we are interested in is increasing and 


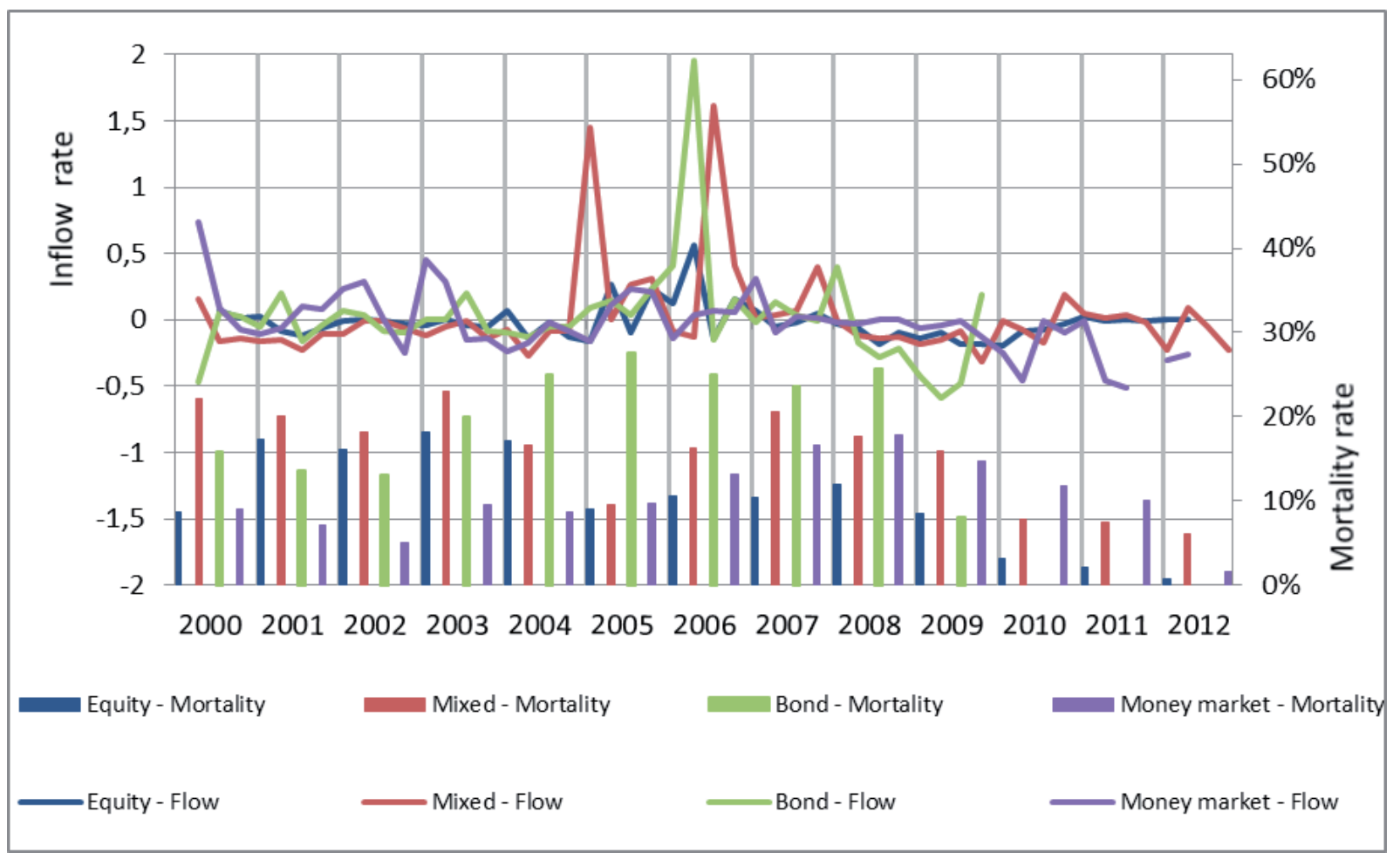

Fig. 2. Average quarterly net inflow of non-surviving funds and yearly mortality rates (Source: own study).

the situation of mutual fund industry becomes more stable. The larger size of samples will enable us to divide funds depending on the value of their assets. Moreover, poor performance factor in mortality analysis should be also taken into consideration.

\section{Conclusions}

The results obtained from the analysis of 13 -year period provide very limited evidence of the influence of survivorship bias on the returns achieved by mutual funds in Hungary. Moreover, the analyzed bias has various significance across the groups of funds with different investment objectives.

The analysis does not confirm significant influence of survivorship bias on the returns of surviving equity funds. However, the influence of market factors on the ability of funds to survive and achieve worse performance than their non-surviving peers (particularly during the beginning of financial crisis in years 2007-2008), seems interesting as far as equity funds are concerned. A similar indirect conclusion can be drawn from the analysis of the second group. However, the statistically significant survivorship biases for mixed funds were found in mid periods of study independently of the applied research method and measure of return. Different findings were observed for bond funds. In spite of relatively high values of mortality rate the biases in the analyzed subgroups of funds were rather low. Nevertheless, since 2010 no bond funds have been withdrawn from the market, which may stem from the financial market situation, and to be more precise it may be related with the reform of pension system in Hungary. The analysis of money market funds showed that survivorship bias was significant during the time of the dynamic changes in financial markets - but in this case the number of non-survivors was small.

The method proposed by Malkiel provides slightly stronger evidences confirming the null hypothesis about the influence of survivorship bias on mutual fund performance in Hungary than the research approach of Elton-Gruber-Blake. Furthermore, since the majority of calculated Jensen's alphas was statistically insignificant, the results obtained by means of this particular measure of returns were unimportant as far as general findings are concerned.

The limitations of the employed database as well as the time horizon under study have made it possible to draw only indirect conclusions regarding the reasons for the liquidation of funds in Hungary. The influence of market conditions on the funds' ability to survive was partially confirmed, especially in the cases of dynamic changes on financial market and during the reform of pension system in Hungary. There is also a moderate relationship existing between the dissolution and asset outflow of failed funds resulting from financial market situation to be observed in particular sub-periods. 


\section{References}

1 Ackermann C., McEnally R., Ravenscraft D., The Performance of Hedge Funds: Risk, Return, and Incentives. Journal of Finance, 54(3), 833-874 (1999). DOI: $10.1111 / 0022-1082.00129$

2 Barbone L, The Battle Over Private Pensions. CASE Network E-briefs No. 05/2011 (2011).

3 Blake Ch. R., Elton E. J., Gruber M. J., The Performance of Bond Mutual Funds. The Journal of Business, 66(3), 371-403 (1993).

4 Bohl M. T., Lischewski J., Voronkova S., Pension Funds' Performance in Strongly Regulated Industries in Central Europe: Evidence from Poland and Hungary, Centre for European Economic Research (ZEW). Discussion Paper No. 10-076 (2010).

5 Brown S. J., Goetzmann W., Ibbotson R. G., Ross S. A. Survivorship bias in performance studies. The Review of Financial Studies, 5(4), 553-580 (1992). DOI: $10.1093 / \mathrm{rfs} / 5.4 .553$

6 Bu Q., Lacey N., Exposing Survivorship Bias in Mutual Fund Data. Journal of Business and Economics Studies, 13(1), 22-37 (2007).

7 Carhart M. M., On Persistence in Mutual Fund Performance. Journal of Finance, 52(1), 57-82 (1997). DOI: $\underline{10.1111 / \mathrm{j} .1540-6261.1997 . t b 03808 . x}$

8 Elton E. J., Gruber M. J., Blake Ch. R., Survivorship bias and mutual fund performance. The Review of Financial Studies, 9(4), 1097-1120 (1996). DOI: $\underline{10.1093 / \mathrm{rfs} / 9.4 .1097}$

9 Erdős P., Ormos M., Return calculation methodology: Evidence from the Hungarian mutual fund industry. Acta Oeconomica, 59(4), 391-409 (2009).

DOI: $10.1556 /$ AOecon.59.2009.4.2
10 Filip D., Performance Persistence of Equity Funds in Hungary. Contemporary Economics, 5(1), 18-34 (2011). DOI: $10.5709 /$ ce.1897-9254.2

11 Filip D., The Analysis of Czech Investment Funds Performance. Ekonomické Listy, 9, 22-39 (2011).

12 Gabryelczyk K., Efekt przetrwania i wyniki inwestycyjne funduszy inwestycyjnych $w$ Polsce [Survivorship Bias and Mutual Funds Performance in Poland]. in 'Inwestycje finansowe i ubezpieczenia tendencje światowe a rynek polski (eds.: Jajuga K.)' Wydawnictwo AE we Wrocławiu, Wroclaw, 176-184 (2005).

13 Grinblatt M., Titman S., Mutual Fund Performance: An Analysis of Quarterly Portfolio Holdings, The Journal of Business, 62(3), 393416 (1989).

14 Jackowicz K., Kowalewski O., Kozłowski Ł., The Short and Long Term Performance Persistence in the Central European Banking Industry, Contemporary Economics, 5(4), 18-31 (2011). DOI: $10.5709 / \mathrm{ce} .1897-9254.25$

15 Jensen M. C., The Performance of Mutual Funds in the Period 1945-1964. Journal of Finance, 23(2), 389-416 (1968). DOI: $10.1111 /$ j.1540-6261.1968.tb00815.x

16 Liang B, Hedge Funds: The Living and the Dead, Journal of Financial and Quantitative Analysis, 35(3), (2000), 309-326.

17 Malkiel B. G., Returns from Investing in Equity Mutual Funds 1971 to 1991. Journal of Finance, 50(2), 549-572 (1995). DOI: $10.1111 / \mathrm{j} .1540-6261.1995 . t b 04795 . x$

18 Simonovits A., The Mandatory Private Pension Pillar in Hungary: An Obituary. Discussion Papers MT-DP - 2011/12, Institute of Economics, Hungarian Academy of Sciences, Budapest (2011). 